\title{
Optimization of Surface Treatment of Carbon Steel in Area of Adhesive Bonding Technology with Application of Quik-Setting Adhesives
}

Miroslav Müller, Petr Valášek

Faculty of Engineering, Czech University of Life Sciences Prague. Czech Republic. E-mail: muller@tf.czu.cz, valasekp@tf.czu.cz

A production stroke has to be taken into regard also at using bonding methods. A limit in an area of the adhesive bonding technology is long hardening time which is needed for reaching a handling strength. Second solution is using quick hardened adhesives (cyanoacrylates). Second limit is a necessity to treat the adhesive bonded surface which is regarded in production companies as another cost and a problem in an area of a waste economy.

The paper deals with the necessity to mechanically treat the adhesive bonded surface, that means an influence of links in the boundary of the adhesive bonded material and the adhesive. The aim of the research is to set the influence of the mechanical and chemical surface treatment of the steel surface at an application of cyanoacrylate adhesives on a strength of the adhesive bond.

Keywords: Adhesive bond strength, Cyanoacrylates, Deformation, Failure area, Structural steel

\section{Acknowledgement}

This paper has been done when solving the grant IGA TF (No.: 2014:31140/1312/3133).

\section{References}

[1] MÜLLER, M., CHOTĚBORSKÝ, R., KRMELA, J. (2007). Technological and constructional aspects affecting bonded joints. In: Research in Agricultural Engineering, Vol. 53 pp. 67-74.

[2] MÜLLER, M. (2013). Research of renovation possibility of machine tools damage by adhesive bonding technology. In: Manufacturing Technology, Vol. 13, pp. 504-509.

[3] VOTAVA, J. (2013). Protection of welded joints against corrosion degradation. In: Acta Universitatis Agriculturae et Silviculturae Mendelianae Brunensi,s Vol. 61, pp. 1897-1904.

[4] MÜLLER, M. (2014). Influence of adhesives storing temperature on adhesive bond strength. In: Manufacturing Technology, Vol. 14, pp. 71-75.

[5] MÜLLER, M, VALÁŠEK, P. (2014). The logistics aspects influencing the resultant strength of adhesives at practical application. In: Agronomy Research, Vol. 12, pp. 285-290.

[6] NOVÁK, M. (2012). Surfaces with high precision of roughness after grinding. In: Manufacturing technology, Vol. 12 , pp. 66 $-70$.

[7] NOVÁK, M. (2011). Surface quality of hardened steels after grinding. In: Manufacturing technology, Vol. 11, pp.55-59.

[8] HOLEŠOVSKÝ, F., NÁPRSTKOVÁ, N., NOVÁK, M. (2012). GICS for grinding process optimization. In: Manufacturing technology, Vol. 12, pp. 22-26.

[9] NAITO, K., ONTA, M., KOGO, Y. (2012). The Effect of Adhesive Thickness on Tensile and Shear Strength of Polyimide Adhesive. In: International Journal of Adhesion \& Adhesives, Vol. 36, pp. 77-85.

[10] SONG, M., ET. AL. (2010). Effect of Manufacturing Methods on the Shear Strength of Composite Single-lap Bonded Joints. In: Composite Structures, Vol. 92, pp. 2194-2202.

[11] XU, W., WEI, Y. (2013). Influence of Adhesive Thickness on Local Interface Fracture and Overall Strength of Metallic Adhesive Bonding Structures. In: International Journal of Adhesion and Adhesives, Vol. 40, pp. 158-167.

[12] MÜLLER, M, VALÁŠEK, P. (2013). Assessment of Bonding Quality for Several Commercially Available Adhesives. In: Agronomy Research Vol. 11, pp. 155-162.

[13] MÜLLER, M. (2013). Research of Liquid Contaminants Influence on Adhesive Bond Strength Applied in Agricultural Machine Construction. In: Agronomy Research, Vol.11, pp. 147-154.

[14] MÜLLER, M. (2011). Influence of Surface Integrity on Bonding Process. In: Research in Agricultural Engineering, Vol. 57, pp. $153-162$.

[15] RUDAWSKA, A. (2014). Selected aspects of the effect of mechanical treatment on surface roughness and adhesive joint strength of steel sheets. In: International Journal of Adhesion and Adhesives, Vol. 50, pp. 235-243.

[16] SHANID, M., HASHIM, S.A. (2002). Effect of Surface Roughness on the Strength of Cleavage Joints. In: International Jurnal of Adhesion \& Adhesives, Vol. 22, pp. 235-244. 
[17] MÜlLER, M. (2012). Použití kyanoakrylátových lepidel v praxi. In Strojírenská technologie, Vol. 17, pp. 326-330.

[18] PROLONGO, SG., ET AL. (2006). Comparative study on the adhesive properties of different epoxy resins. In: International Journal of Adhesion \& Adhesives, Vol. 26, pp. 125-132.

[19] UEHARA, K.., SAKURAI, M. (2002). Bonding strength of adhesives and surface roughness of joined parts. In: Journal of Materials Processing Technology, Vol. 127, pp. 178-181.

[20] LUNDER, O., ET AL. (2004). Effect of pre-treatment on the durability of epoxy-bonded AA6060 aluminium joints. In: International Journal of Adhesion \& Adhesives, Vol. 24, pp. 107-117.

[21] BJORGUM, A., ET AL. (2003). Anodising as pre-treatment for structural bonding. In: International Journal of Adhesion \& Adhesives, Vol. 23, pp. 401-412.

[22] CHEN, S., ET AL. (1997). Improvement of the adhesion of the resin to the metal surface by using plasma jet. In: Surface and Coating Technology, Vol. 97, pp. 378-384.

[23] COMYN, J. (1990). Surface treatment and analysis for adhesive bonding. In: International Journal of Adhesion \& Adhesives, Vol. 10, p. 161-165.

Paper number: M2014107

Copyright (C) 2014. Published by Manufacturing Technology. All rights reserved. 